\title{
Current methodological Issues in Candidate Gene Association Studies in Psychiatric Disorders
}

\section{Leo Sher M.D.}

National Institute of Mental Health, Bethesda, MD; Department of Neuroscience, New York State Psychiatric Institute; Columbia University, New York, NY

Follow this and additional works at: https://jdc.jefferson.edu/jeffjpsychiatry

Part of the Psychiatry Commons

Let us know how access to this document benefits you

\section{Recommended Citation}

Sher, Leo M.D. (2002) "Current methodological Issues in Candidate Gene Association Studies in Psychiatric Disorders," Jefferson Journal of Psychiatry. Vol. 17 : Iss. 1 , Article 6.

DOI: https://doi.org/10.29046/JJP.017.1.005

Available at: https://jdc.jefferson.edu/jeffjpsychiatry/vol17/iss1/6

This Article is brought to you for free and open access by the Jefferson Digital Commons. The Jefferson Digital Commons is a service of Thomas Jefferson University's Center for Teaching and Learning (CTL). The Commons is a showcase for Jefferson books and journals, peer-reviewed scholarly publications, unique historical collections from the University archives, and teaching tools. The Jefferson Digital Commons allows researchers and interested readers anywhere in the world to learn about and keep up to date with Jefferson scholarship. This article has been accepted for inclusion in Jefferson Journal of Psychiatry by an authorized administrator of the Jefferson Digital Commons. For more information, please contact: JeffersonDigitalCommons@jefferson.edu. 


\title{
Current Methodological Issues in Candidate Gene Association Studies in Psychiatric Disorders
}

\author{
Leo Sher, M.D.
}

\begin{abstract}
One of the most rapidly emerging areas of neuroscience research is the study of genetic approaches to complex psychiatric disorders. The author discusses potential benefits and pitfalls of candidate gene association studies. Association studies search for correlations in the population between a DNA marker and a disorder. The so-called candidate gene approach is frequently used in association studies. Candidate gene studies are usually based on hypotheses about relationships between specific known loci and particular phenotypes. The aim of molecular genetic studies of behavioral disorders includes the development of predictive and diagnostic testing for psychiatric disorders that can help to establish the accurate diagnosis and the identification of target for therapeutic drugs. To date, case-control association studies investigating polymorphisms of candidate genes in psychiatric disorders have produced a lot of positive and negative findings with few consistent replications. The false positive and false negative findings in candidate gene association studies are due to population stratification, heterogeneity of psychiatric disorders, multiple tests, low prior odds of association, and small sample size. A researcher planning a genetic association study for a psychiatric disorder needs to have the following: 1) suitable phenotypes; 2) a good rationale for studying not only the gene in question, but the specific polymorphism; 3) enough subjects and control for meaningful analyses; and 4) use of ethnically homogenous case-control data sets or family based association designs.
\end{abstract}

\section{INTRODUCTION}

A long time ago people have recognized that behavioral disorders run in families $(1,2)$. Theories about the inheritance of behavior date to ancient Greece. It has been suggested that Hippocrates (460-377 B.C.) was the first to stress heredity and predisposition in relation to psychiatric diseases (3). The relationship between heredity and psychiatric disease was also noted by another ancient scholar-

At the time of writing this paper Dr. Sher was Senior Staff Fellow, National Institute of Mental Health, Bethesda, MD. At the present time, he is Research Psychiatrist, Department of Neuroscience, New York State Psychiatric Institute, and Assistant Clinical Professor of Psychiatry, Columbia University, New York, NY.

Address for correspondence: Leo Sher, M.D., Department of Neuroscience, New York State Psychiatric Institute, 1051 Riverside Drive, Suite 2917, Box 42, New York, NY 10032. Tel: 212-543-6240 Fax: 212-543-6017 E-mail: leosher@neuron.cpmc.columbia.edu 
Euripides (484-406 B.C.) (4). Felix Plater (1536-1614) is regarded as one of the earliest classifiers of psychiatric disorders (3). In his effort to study psychiatric illness, he classified mental disorders into acquired, congenital, and hereditary afflictions. Robert Burton (1577-1640) wrote in his book The Anatomy of Melancholy that the "inbred cause of melancholy is our temperature, in whole or part, which we receive from our parents" and "such as the temperature of the father is, such is the son's, and look what disease the father had when he begot him, his son will have after him" (5). Burton continued, "I need not therefore to make any doubt of melancholy, but that it is an hereditary disease."

The study of genetics is changing our understanding of the world. Just as we cannot step in the same river twice, we will never be able to see the world in the same way as we did before the recent discoveries in behavioral genetics. The promise of genetic research is very considerable, and the resources put into genetic research reflects this. One of the most rapidly emerging areas of neuroscience research is the study of genetic approaches to complex psychiatric disorders. Family, twin, and adoption studies have produced data that firmly support the genetic basis for the inheritance of psychiatric disorders.

Genetic factors can interact with environmental factors to influence the vulnerability to psychiatric disorders in different ways (6-12). For example, Kendler (6) explored two such mechanisms: "genetic control of sensitivity to environment," and "genetic control of exposure to the environment." "Genetic control of sensitivity to the environment" suggests that genes, in part, render individuals relatively vulnerable or relatively invulnerable to the pathogenic effects of environmental stress. The depressogenic effect of stressful life events is substantially greater in those at high versus low genetic risk to the mood disorders. "Genetic control of exposure to the environment" suggests that genetic factors influence the probability that individuals will select themselves into high vs. low risk environments. The genetic risk factors for major depression in part express themselves by influencing the probability that individuals will experience stressful life events, particularly of an interpersonal nature.

\section{ASSOCIATION STUDIES}

Molecular genetic studies attempt to identify the specific allele that may be responsible for the familiality and heritability of phenotype $(7-9,13)$. In the last ten years, there has been a considerable interest in candidate gene association studies of psychiatric disorders (7-9,13-17).

All humans have considerable genetic variation, or polymorphism $(8,9,13)$. A gene is called polymorphic if no single form of the gene has an abundance of more than $99 \%$ in a population. Gene variants, including polymorphisms, are related to the development of diseases that are genetically influenced. Association studies search for correlations in the population between a DNA marker and a disorder. In other words, association studies compare distributions of marker alleles in cases and controls. If persons with a disorder have an increased frequency of a specific allele, 
or genotype, it may mean that the gene contributes to vulnerability to the disease. The so-called candidate gene approach is frequently used in association studies (7-9,13-17). Candidate gene studies are usually based on hypotheses about relationships between specific known loci and particular phenotypes. When biological investigations have provided some clue as to the possible involvement of known genes, these genes may become candidates for studies. Although candidate gene studies in psychiatry have been criticized because of our limited knowledge of the underlying pathophysiology of illness, there is also much we do know. For example, we do know that the serotonergic system is involved in the pathophysiology of mood disorders $(11,18)$.

In the search for candidate genes, those physiological and biochemical systems that have been theorized to be important in the pathogenesis of behavioral disorders are logical ones on which to focus $(8,9,13)$. One starting point for understanding vulnerability to behavioral disorders is to look for variants in genes involved in neurotransmitter metabolism. Genes for receptors, transporters, and metabolizing enzymes are good candidates. Because of the complexity of causation of psychiatric disorders, any genetic determinants of vulnerability to psychiatric disorders are likely to be subtle. A gene variant found to be associated with a disorder may be neither necessary nor sufficient to cause the illness; rather, it is an indicator of the relative risk or susceptability.

\section{BENEFITS}

The aim of molecular genetic studies of behavioral disorders includes the development of predictive and diagnostic testing for psychiatric disorders that can help to establish the accurate diagnosis and the identification of target for therapeutic drugs $(8,9,19)$. Successful pharmacological treatment of patients with psychiatric disorders suggests the existence of biologic pathways in which genetic variation is likely to affect liability to behavioral disorders and treatment response. Drug therapy in the future may be personalized: the choice of drug may be determined by the genes a patient carries.

Studies of the genetics of psychiatric diseases can also help us to understand better the role of environmental factors in the development of these disorders $(6,8,9,20-22)$. The triggering of psychiatric disorders may be influenced by complex interactions of genetic factors with multiple environmental components. Molecular genetic research may help to elucidate causal processes as they apply to both brain systems and nature-nurture interplay.

\section{INCONSISTENT RESULTS OF CANDIDATE GENE ASSOCIATION STUDIES IN PSYCHIATRIC DISORDERS}

By the present time, case-control association studies investigating polymorphisms of candidate genes in psychiatric disorders have produced a lot of positive and negative findings with few consistent replications. 
Collier et al. (23) found that a short variant of the serotonin transporter-linked polymorphic region (5-HTTLPR) is associated with bipolar disorder and unipolar depression. However, Mendes de Oliveira et al. (24), Gutierrez et al. (25), and Kunugi et al. (26) reported no association between the 5-HTTLPR polymorphism and bipolar disorder. Rees et al. (27) found that the 5-HTTLPR polymorphism is not associated with bipolar disorder and unipolar depression.

Schmidt et al. (28), Sander et al. (29,30) and Hallikainen et al. (31) found that the frequency of the short allele of the 5-HTTLPR is significantly increased in alcoholic patients with severe dependence as compared with nonalcoholic control subjects. Similar results were reported by Hammoumi et al. (32) and Lichtermann et al. (33). Thompson et al. (34) reported a trend toward increased frequency of the short allele in alcohol-dependent subjects. Turker et al. (35) found the existence of a significant association between the short allele of the serotonin transporter gene promoter and high ethanol tolerance in young adults. In contrast, Edenberg et al. (36), Jorm et al. (37) and Gorwood et al. (38) did not find an association between the 5-HTTLPR and alcohol misuse or dependence.

Ogilvie et al. (39) reported an association between unipolar depression and a nine-repeat allelic variant of a variable tandem repeat (VNTR) marker in the second intron of the serotonin transporter gene. Three subsequent studies did not find this association (40-42).

Collier et al. (43) and Rees et al. (27) found that a nine-repeat allelic variant of a VNTR marker in the second intron of the serotonin transporter gene is associated with bipolar disorder. Hoehe et al. (42) reported that the polymorphism of the VNTR is not associated with susceptibility to bipolar disorder.

A 5-HT2A receptor promoter polymorphism, -1438G/A, was reported to be associated with susceptibility to anorexia nervosa (44-46). However, Campbell et al. (47) and Ando et al. (48) found lack of association between the 5-HT2A gene promoter polymorphism and anorexia nervosa.

Two studies showed that the personality trait of Novelty Seeking is associated with a polymorphic exon III repeat sequence at the dopamine D4 receptor gene locus $(49,50)$. Several subsequent studies did not confirm these findings (51-54).

There are many more inconsistent and conflicting results of association studies in behavioral genetics $(16,17,55-58)$. A few examples exist of success using association to find genes for complex diseases (59-61). An association between the apolipoprotein E (APOE) gene and sporadic Alzheimer's disease was a primary chance finding with limited biological guidance (60), and in insulin-dependent diabetes mellitus (IDDM) the insulin gene was the logical candidate for IDDM (61). There is a handful of replicated findings in complex traits. However, hundreds of initially positive results are not subsequently replicated. It is clear that there are difficulties and limitations related to case-control association studies.

\section{LIMITATIONS}

A major problem of case-control association studies is that significantappearing relationships may be found as an artifact of genetic differences 
between the cases and controls because population stratification (or admixture) due to ethnic variation or other confounding factors can generate considerable population differences in marker allele frequencies $(8,9,13-17,57,59)$. It has been proposed that family-based studies that compare cases with relatives can eliminate such artifacts $(62,63)$. However, intra-familial association studies do not overcome the problem of ethnic differences in disease etiology (there may be differences in the contribution of a given allele in different ethnic groups) or allelic association due to tight linkage (a disease locus and the associated marker locus may be tightly linked, that is, physically close to each other) (16,57). Even when intra-familial design is used, samples should be drawn from as ethnically a homogeneous population as possible.

Another major problem of studies in psychiatric genetics is that psychiatric diagnoses are not known to be biologically homogenous entities: syndromal psychiatric diagnostic categories such as depression or anxiety disorders potentially include etiologically, pathologically, and prognostically heterogenous disorders (64-68). The broad categorical classification of behavioral disorders that is used in psychiatry at the present time is not suitable for genetic association studies. At the present time psychiatric phenotypes are so broad that researchers cannot establish the defining relationship between the behavior and the genes. In other words, failure to obtain convincing results in psychiatric genetics can partly be attributed to the fact that progress in molecular biology has not been followed by an equivalent development in phenotypic description. The important and complex problem is how to get more homogenous and more narrowly defined phenotypes. Identification of a plausible biological marker would probably be the optimal measure for refining the disease phenotype. Numerous ideas related to this matter have been suggested. Tsuang and Faraone (69) proposed the concept of target features. Target features are clinical or neurobiological characteristics that are expressions of the underlying vulnerability to a disease. Target features may be more closely linked to brain function than clinical psychiatric phenotypes and, therefore, may be credible biological markers in genetic studies. To reduce the heterogeneity of schizophrenia Carpenter et al. (70) proposed to differentiate between deficit and non-deficit schizophrenia (genetic vulnerability for deficit and non-deficit schizophrenia may be different). Better definition of the phenotype can enhance the chance of detecting significant associations. Success in genetic research will depend on examining more homogenous and more narrowly defined phenotypes.

The false positive and false negative findings in candidate gene association studies are not only due to population stratification or heterogeneity of psychiatric disorders, but probably often to multiple tests, low prior odds of association, and small sample size $(13,16,57)$. If a great number of patient-control comparisons are made one or several 'significant' allelic associations will be found even if no true association exists. It is rarely possible to define highly credible candidates and the prior odds against true association are very considerable. Many negative studies have very little power to detect moderate or small effect sizes. 


\section{CONCLUSION}

Mental disorders are very challenging to genetic researchers because they do not stem from errors in single genes. Besides, both genes and environment appear to be complexly and interactively involved in the development of mental disorders, perhaps with multiple components of each. Furthermore, a mental disorder such as schizophrenia may be at the most severe end of a continuum of schizophrenias that include schizoaffective disorder, schizophreniform disorder, schizotypal personality disorder, and possibly other variants. Growing scientific evidence suggests that other major psychiatric disorders may follow the same pattern.

The behavioral genetic research road is long and difficult one with many problems to be overcome. A researcher planning a genetic association study for a psychiatric disorder needs to have the following $(8,9,14,16,57,71): 1)$ suitable phenotypes; 2) a good rationale for studying not only the gene in question, but the specific polymorphism; 3) enough subjects and control for meaningful analyses; and 4) use of ethnically homogenous case-control data sets or family based association designs.

The practical implications of identifying numerous genes with minor effects remain debatable. Detecting candidate genes with even a small effect is important if the genes are tied to a functional change involved in the pathogenesis of a complex disease that likely reflect the action of many genes.

It is to be hoped that efforts of psychiatric geneticists will be rewarding. Future research may clarify the role of different genes in the development of psychiatric disorders. Genetic studies may advance our understanding not only of the role of genetic factors in the etiology of psychiatric disorders but may also be useful in refining conceptions of psychiatric disorders themselves, and possible approaches to the treatment of these conditions. There is a hope that the progress of science in the $20^{\text {th }}$ century will be dwarfed by the immense progress of the $21^{\text {st }}$, and that behavioral genetics will be part of it.

\section{REFERENCES}

1. Sher L. Early recognition of inherited disorders. Am J Psychiatry 2001; 158: 1527-1528.

2. Sher L. Centuries ago scholars had knowledge about inheritance of psychiatric disorders and behavioral traits. Med Hypotheses, in press.

3. Schneck JM: A History of Psychiatry. Springfield, Ill, Charles C Thomas, 1960, pp. 18, 43.

4. Mettler CC, Mettler FA: History of Medicine: A Correlative Text, Arranged According to Subjects. Philadelphia, Blakiston, 1947, p. 495.

5. Burton R: The Anatomy of Melancholy [1932]. New York, Random House, 1977, pp. 211-212.

6. Kendler KS. Major depression and the environment: a psychiatric genetic perspective. Pharmacopsychiatry 1998; 31: 5-9.

7. Reus VI, Freimer NB. Understanding the genetic basis of mood disorders: where do we stand? American Journal of Human Genetics 1997; 60: 1283-1288.

8. Genetic influences on neural and behavioral functions. Pfaff DW, Berretini WH, Joh TH, Maxson SC, eds. Boca Raton, Florida: CRC Press, 2000. 
9. Handbook of Psychiatric Genetics. Blum K, Noble EP, eds. Boca Raton, Florida: CRC Press, 1997.

10. Johansson C, Jansson M, Linnér L, Yuan QP, Pedersen NL, Blackwood D, Barden N, Kelsoe J, Schalling M. Genetics of affective disorders. European Neuropsychopharmacology 2001; 11: 385-394.

11. Dubovsky SL, Buzan R. Mood disorders. In: Hales RE, Yudofsky SC, Talbott JA. The American psychiatric Press Textbook of Psychiatry. Washington, DC: Amer Psychiatr Press, 1999, pp. 479-565.

12. McGue M, Bouchard TJ, Jr. Genetic and environmental influences on human behavioral differences. Annu Rev Neurosci 1998; 21: 1-24.

13. Moldin SO, Gottesman II. Population genetic methods in psychiatry. In: Kaplan's and Sadock's Comprehensive Textbook of Psychiatry. Sadock BJ, Sadock VA, eds. $7^{\text {th }}$ edn. 2000, vol. 1, pp. 172-183.

14. Buckland PR. Genetic association studies of alcoholism - problems with the candidate gene approach. Alcohol \&Alcoholism 2001; 36: 99-103.

15. Sher L. Candidate gene association studies in psychiatric disorders: promises and limitations. J Psychiatry Neurosci 2001; 26: 103-105.

16. Owen MJ, Holmans P, McGuffin P. Association studies in psychiatric genetics. Mol Psychiatry 1997; 2: 270-273.

17. Hrdina PD. Genetic association studies in psychiatry. Are we putting the cart before the horse? J Psychiatry Neurosci 1998; 23: 211-213.

18. Sher L, Mann JJ. Pathophysiology of mood disorders. In: Lieberman JA, Kay J, Tasman A (eds). Psychiatry. London: John Wiley \& Sons, in press.

19. Werner K. Pharmacogenetic research: a revolutionary science. J Psychiatry Neurosci 1999; 24: $139-140$.

20. McEwen BS. Allostasis and allostatic load: implications for neuropsychopharmacology. Neuropsychopharmacology 2000; 22: 108-124.

21. Rutter M, Plomin R. Opportunities for psychiatry from genetic findings. Br J Psychiatry 1997; 171: 209-219.

22. Sher L, Goldman D, Ozaki N, Rosenthal NE. The role of genetic factors in the etiology of seasonal affective disorder and seasonality. J Affect Disord 1999; 53: 203-210.

23. Collier DA, Stober G, Li T., et al. A novel functional polymorphism within the promoter of the serotonin transporter gene: possible role in susceptibility to affective disorders. Mol Psychiatry 1996; 1: 453-460.

24. Mendez de Oliveira JR, Otto PA, Vallada H, et al. Analysis of a novel functional polymorphism within the promoter region of the serotonin transporter gene (5-HTT) in Brazilian patients affected by bipolar disorder and schizophrenia. Am J Med Genet 1998; 81: 225-227.

25. Gutierrez B, Arranz MJ, Collier DA, et al. Serotonin transporter gene and risk for bipolar affective disorder: an association study in Spanish population. Biol. Psychiatry 1998; 43: 843-847.

26. Kunugi H, Hattori M, Kato T, et al. Serotonin transporter gene polymorphisms: ethnic difference and possible association with bipolar affective disorder. Mol Psychiatry 1997; 2: 457-462.

27. Rees M, Norton N, Jones I, et al. Association studies of bipolar disorder at the human serotonin transporter gene (hSERT; 5HTT). Mol Psychiatry 1997; 2: 398-402.

28. Schmidt L, Rommelspacher H, Lesch KP, Sander T. Variants of the dopamine and serotonin transporter genes and alcohol withdrawal vulnerability. Am J Med Genet 1997; 6: 621-622. 
29. Sander T, Harms H, Lesch KP, Dufeu P, Kuhn S, Hoehe M, et al. Association analysis of a regulatory variation of the serotonin transporter gene with severe alcohol dependence. Alcohol Clin Exp Res 1997; 21: 1356-1359.

30. Sander T, Harms H, Dufeu P, Kuhn S, Hoehe M, Lesch KP, et al. Serotonin transporter gene variants in alcohol-dependent subjects with dissocial personality disorder. Biol Psychiatry 1998; 43: 908-9912.

31. Hallikainen T, Saito T, Lachman HM, Volavka J, Pohjalainen T, Ryynanen OP, et al. Association between low activity serotonin transporter promoter genotype and early onset alcoholism with habitual impulsive violent behavior. Mol Psychiatry 1999; 4: 385-388.

32. Hammoumi S, Payen A, Favre JD, Balmes JL, Benard JY, Husson M, et al. Does the short variant of the serotonin transporter linked polymorphic region constitute a merker of alcohol dependence? Alcohol 1999; 17: 107-112.

33. Lichtermann D, Hranilovic D, Trixler M, Franke P, Jernej B, Delmo CD, et al. Support for allelic association of a polymorphic site in the promoter region of the serotonin transporter gene with risk for alcohol dependence. Am J Psychiatry 2000; 157: 2045-2047.

34. Thompson MD, Gonzalez N, Nguen T, Comings DE, George SR, O'Dowd BF. Serotonin transporter gene polymorphisms in alcohol dependence. Alcohol 2000; 22: 61-67.

35. Turker T, Sodmann R, Goebel U, Jatzke S, Knapp M, Lesch KP, et al. High ethanol tolerance in young adults is associated with the low-activity variant of the promoter of the human serotonin transporter gene. Neurosci Lett 1998; 248: 147-150.

36. Edenberg HJ, Reynolds J, Koller DL, Begleiter H, Bucholz KK, Conneally PM, et al. A family-based analysis of whether the functional promoter alleles of the serotonin transporter gene HTT affect the risk for alcohol dependence. Alcohol Clin Exp Res 1998; 22: $1080-1085$.

37. Jorm AF, Henderson AS, Jacomb PA, Christensen H, Korten AE, Rodgers B, et al. An association study of a functional polymorphism of the serotonin transporter gene with personality and psychiatric symptoms. Mol Psychiatry 1998; 3: 449-451.

38. Gorwood P, Batel P, Ades J, Hamon M, Boni C. Serotonin transporter gene polymorphisms, alcoholism, and suicidal behavior. Biol Psychiatry 2000; 48: 259-264.

39. Ogilvie AD, Battersby S, Bubb VJ, et al. Polymorphism in the serotonin transporter gene associated with susceptibility to major depression. Lancet 1996; 347: 731-733.

40. Kunugi H, Tatsumi M, Sakai T, Hattori M, Nanko S. Serotonin transporter gene polymorphism and affective disorder. Lancet 1996; 347: 1340.

41. Stober G, Heils A, Lesch KP. Serotonin transporter gene polymorphism and affective disorder. Lancet 1996; 347: 1340-1341.

42. Hoehe MR, Wendel B, Grunewald I, et al. Serotonin transporter (5-HTT) gene polymorphisms are not associated with susceptibility to mood disorders. Am J Med Genet 1998; 81: 1-3.

43. Collier DA, Arranz MJ, Sham P, et al. The serotonin transporter is a potential susceptibility factor for bipolar affective disorder. NeuroReport 1996; 7: 1675-1679.

44. Collier DA, Arranz MJ, Li T, Mupita D, Brown N, Treasure J. Association between 5-HT2A gene promoter polymorphism and anorexia nervosa. Lancet 1997; 350: 412.

45. Enoch MA, Kaye WH, Rotondo A, Greenberg BD, Murphy DL, Goldman D. 5-HT2A promoter polymorphism -1438, anorexia nervosa, and obsessive-compulsive disorder. Lancet 1998; 351: 1785-1786.

46. Sorbi S, Nacmias B, Tedde A, Ricca V, Mezzani B, Rotella CM. 5-HT2A promoter polymorphism in anorexia nervosa. Lancet 1998; 351: 1785.

47. Campbell DA, Sundaramurthy D, Markham AF, Pieri LF. Lack of association between 
5-HT2A gene promoter polymorphism and susceptibility to anorexia nervosa. Lancet 1998; 351: 499.

48. Ando T, Komaki G, Karibe M, et al. 5-HT2A promoter polymorphism is not associated with anorexia nervosa in japanese patients. Psychiatr Genet 2001; 11: 157-160.

49. Ebstein RP, Novick O, Umansky R, et al. Dopamine D4 receptor (D4DR) exon III polymorphism associated with the personality trait of Novelty Seeking in normal human volunteers. Nature Genet 1996; 12: 78-80.

50. Benjamin J, Li L, Patterson C, Greenberg BD, Murphy DL, Hamer DH. Population and familial association between the D4 dopamine receptor gene and measures of Novelty Seeking. Nature Genet 1996; 12: 81-84.

51. Malhotra AK, Virkkunen, Rooney W, Eggert M, Linnoila M, Goldman D. The association between the dopamine D4 receptor (D4DR) 16 amino acid repeat and novelty seeking. Mol Psychiatry 1996; 1: 388-391.

52. Johnsson EG, Nothen MM, Gustavsson JP et al. Lack of evidence for allelic association between personality traits and the dopamine D4 receptor gene polymorphism. Am J Psychiatry 1997; 154: 697-699.

53. Vandenbergh DJ, Zonderman AB, Wang J, Uhl JR, Costa PT Jr. No association between Novelty seeking and dopamine D4 receptor (D4DR) exon III seven repeat alleles in Baltimore Longitudinal Study of Aging participants. Mol Psychiatry 1997; 2: 417-419.

54. Gelertner J, Kranzler H, Coccaro E, Siever L, New A, Mulgrew CL. D4 dopamine-receptor (DRD4) alleles and novelty-seeking in substance-dependent, personality-disorder, and control subjects. Am J Hum Genet 1997; 64: 1144-1152.

55. Baron M. Mapping genes for personality: is the saga sagging? Mol Psychiatry 1998; 3: $106-108$.

56. Greenberg BD, McMahon FJ, Murphy DL. Serotonin transporter candidate gene studies in affective disorders and personality: promises and potential pitfalls. Mol Psychiatry 1998; 3: 186-189.

57. Owen MJ, Cardno AG, O'Donovan MC. Psychiatric genetics: back to the future. Mol Psychiatry 2000; 5: 22-31.

58. Sullivan PF, Eaves LJ, Kendler KS, Neale MC. Genetic case-control association studies in neuropsychiatry. Arch Gen Psychiatry 2001; 58: 1015-1024.

59. Paterson AD. Case-control association studies in complex traits - the end of an era? Mol Psychiatry 1997; 2: 277-278.

60. De Knijff P, van Duijn CM. Role of APOE in dementia: a critical reappraisal. Haemostasis 1998; 28: 195-201.

61. Chowdhury TA, Mijovic CH, Barnett AH. The aetiology of Type I diabetes. Baillieres Best Pract Res Clin Endocrinol Metab 1999; 13: 181-195.

62. Falk CT, Rubinstein P. Haplotype relative risks: an easy reliable way to construct a proper control sample for risk calculations. Ann Hum Genet 1987; 51: 227-233.

63. Schaid DJ, Sommer SS. Comparison of statistics for candidate-gene association studies using cases and parents. Am J Hum Genet 1994; 55: 402-409.

64. Leboyer M, Bellivier F, Nosten-Bertrand M, Jouvent R, Pauls D, Mallet J. Psychiatric genetics: search for phenotypes. Trends Neurosci 1998; 21: 102-105.

65. Sher L. Psychiatric diagnoses and inconsistent results of association studies in behavioral genetics. Med Hypotheses 2000; 54: 207-209.

66. Sher L. Phenotype definition and association studies in behavioral genetics. Mol Psychiatry 1999; 4: 316.

67. Charleton BG. Natural kinds, natural history and the clinician-researcher. QJM 1997; 90: 707-709. 
68. Sher L. Natural kinds, the clinician-researcher and psychiatric diagnoses. QJM 1998; 91 : 245.

69. Tsuang MT, Faraone SV. The concept of target features in schizophrenia research. Acta Psychiatr Scand 1999; 395 Suppl: 2-11.

70. Carpenter WT Jr, Arango C, Buchanan RW, Kirkpatrick B. Deficit psychopathology and a paradigm shift in schizophrenia research. Biol Psychiatry 1999; 46: 352-360.

71. Malhotra A, Goldman D. Benefits and pitfalls encountered in psychiatric genetic association studies. Biol Psychiatry 1999; 45: 544-550. 